\title{
Ummaen, ungdommen og fordringen om enhed og reform: En analyse af den arabiske fredagskhutba i Det Islamiske Trossamfund.
}

\author{
Af Andreas Lysholt Mathiasen
}

\begin{abstract}
This article analyzes the notion of the transnational Islamic community, umma, as it finds expression in Arabic Friday sermons (khutbas) presented at the mosque of The Islamic Society of Believers (Islamisk Trossamfund) in Copenhagen from 2005 to 2011. Khutbas in which the umma plays a significant role tend to focus on Muslim unity, reform and the role of youth as a catalyst of change in the umma. The analysis identifies a shift in the umma discourse in the Copenhagen mosque from a political Islamist discourse to a more apolitical Salafist discourse. Data presented in the article points to the fact that the notion of how change is generated in the umma undergoes a shift from a nationally and politically oriented focus towards a more globally, ritually and morally oriented focus. The aim of the article is not to contribute theoretically to the study of transnationalism and Islam, but rather to present a case study of relevance to the relation between the two. The content of khutbas in Arabic in Denmark has not previously been the focus of much attention from academics and thus the article also intends to direct attention to a Islamic oral genre that is highly relevant for many Muslims and dynamic in its ability to address topics of religious, political and social relevance.
\end{abstract}

I antologien Muslim networks and transnational communities in and across Europe (Allievi og Nielsen 2003) peger Stefano Allievi på, at ikke-muslimer primært skaber deres forståelse af islam på baggrund af den skriftlige litteratur, som muslimer producerer (ibid.: 15). Videre hævder han, at det modsatte sandsynligvis er gældende for flertallet af muslimer selv, da ikke-skrevne medier og orale genrer som fredagskhutbaen og audio-lektioner (durûs) for flertallets vedkommende er mere konsumeret og udbredt end det skrevne ord. Et engagement med muslimer i Europa skal derfor snarere, hævder Allievi, tage sit udgangspunkt i mundtlig orienteret kultur.

Denne fordring ligger bag dataindsamlingen til min specialeafhandling om fredagskhutbaen hos Det Islamiske Trossamfund (DIT), der forsøgte at spore variation og udvikling i khutbaer af organisationens arabisktalende førsteimamer. Ved en kursorisk gennemlytningen og følgende kategorisering af et større antal khutbaer fra perioden 2005 til 2011 noterede jeg, at tilhørsforholdet til ummaen ofte spillede en fremhævet rolle i khutbaerne. Min indledende formodning om, at ummaen særligt bliver inddraget i form af sympatitilkendegivelser i taler om særlige begivenheder i den muslimske verden såsom Palæstina/Israel-konflikten, naturkatastrofer og overgreb på muslimer (C) Forfatteren og Tidsskrift for Islamforskning, ISSN 1901-9580, publiceret 27-4-2012 
(hvor imamen udtrykker en direkte identifikation af menigheden med muslimer i forskellige dele af verden pga. særlige bekymrende begivenheder), viste sig fejlagtig. Ummaen fungerer i højere grad som en potent forestilling i khutbaer om moralsk reform, ungdommens rolle heri og ønsket om enhed muslimer imellem på tværs af nationale skel. Jeg vil i denne artikel fremdrage nogle af disse observationer af, hvordan det globale fællesskab formuleres og produceres i khutbaer i DIT af nogle af organisationens seneste imamer. Hvordan beskrives ummaens nuværende situation, og hvordan karakteriseres det globale muslimske fællesskab? Er der tale om et politisk defineret fællesskab, der udfordrer eller erstatter antagelser af et nationalt politisk fællesskab? Artiklen peger på, at ummaforestillingen formuleres som katalysator for en ønsket forandring, samt at en ideologisk udvikling har fundet sted i DIT i antagelsen af måden, hvorpå denne forandring afstedkommes.

Artiklen er primært en tekstnær og kvalitativ læsning af orale tekster, og ikke et teoretisk studie. Formålet er at gøre centrale forestillinger, der ellers ikke er den brede offentlighed tilgængelig mere klart for interesserede i islamforskningen. Desuden har den arabisksprogede khutba ikke været genstand for megen akademisk interesse, så bag artiklen ligger ligeledes bestræbelser på at anspore interesse for en understuderet islamisk mundtlig genre af stor relevans for mange muslimer.

\section{At studere et transnationale fallesskabsforestillinger}

Stefano Allievi og Jørgen Nielsen (2003) kritiserer tendenser i studiet af muslimer i Europa for at studere muslimske grupper 'i sig selv', hvormed antagelsen af fællesskab tages for givet. I dette perspektiv bliver det konsekvenserne af den muslimske tilstedeværelse, der behandles. Selve produktionen af fællesskab, hvilke midler der tages i anvendelse hertil, og hvad der yder indflydelse herpå, synes, i følge Allievi og Nielsen, at være et understuderet felt. Den ugentlige khutba er en af de primære institutionelt forankrede begivenheder, hvor der ofte sættes ord på fællesskabets karakter. I forbindelse med denne artikels fokus på formuleringen af fællesskab er det værd at bemærke, at forestillingerne om den globale muslimske umma, som præsenteres i denne artikel, finder sit udtryk i en særlig rituel kontekst. Det forhold at fredagskhutbaen udføres som led i en rituel begivenhed, der er bundet af visse retlige regler for ritualets gyldighed, gør dog ikke at khutbaens indhold er standardiseret i en sådan grad at et studie heraf er uinteressant.

Umma som begreb refererer til en forestilling om, at muslimer udgør et fællesskab i kraft af deres religiøse overbevisning. Det er en forestilling om et fællesskab eller en 'nation', der ikke er knyttet 
til nationalstatslige grænser, men går på tværs af disse, og et studie af samme knytter således an til begrebet transnationalitet. I Koranen anvendes ordet primært om religiøse fællesskaber, men i senere tid har ordet mest været forbeholdt det særlige muslimske fællesskab (ordets flertalsform umam anvendes dog i moderne sprogbrug om nationer uden at indebære en religiøs betydning). Udviklingen mod en forståelse af umma som en markør for det muslimske fællesskab udelukker ikke det forhold, at ordet i perioden har været benyttet om eksempelvis både jøder og hele menneskeheden - sidstnævnte i den forstand at de er potentielle muslimer (Denny 2012). I dokumentet, der kendes som Medinatraktaten, beskrives det medinensiske samfund som en umma, som den jødiske umma er kontraktuelt forpligtet til opretholdelse af sikkerhed og forsvar af. Antagelsen af ummaen som en samlet religio-politisk reference harmonerer med det tidlige kalifat som politisk institution, hvor den øverste politiske autoritet i teorien også er fællesskabets religiøse overhoved, og kalifatets institutionelle splittelse under Mamlukerne i Egypten ledte ikke til, at forestillingen om en forenet umma på tværs af politiske og regionale opdelinger blev kasseret (Schulze 2002: 15). I de sidste årtier af det 19. århundrede blev der blandt flere muslimske intellektuelle knyttet fornyet håb til kalifatet som institution og til forestillingen om ummaen som udtryk for muslimernes enhed; baggrunden herfor skal findes i bestræbelserne på at modvirke den europæiske politiske og kulturelle dominans. Kolonialismen bringer med sig en stigende bevidsthed om ummaen som et homogent, transnationalt fællesskab; men et fællesskab, hvor de ledende panislamiske aktører mod begyndelsen af det 20. århundrede ikke ser kalifatet som den rette udøver af suverænitet over ummaen (ibid.: 40). I de senere år har flere forskere interesseret sig for forskellige variationer over muslimske ummaforestillinger i senmoderniteten. Her kan fremhæves forestillingen om 'den virtuelle umma', dvs. særligt internetmedierede forestillinger om muslimsk enhed og fællesskab (se eksempelvis Roy 2007). Her er tale om idealiserede forestillinger om et fællesskab, der ikke er knyttet til nationer, men som eksisterer på tværs heraf. Som Olivier Roy bemærker, står forestillingen om den muslimske enhed, som den formuleres i 'den virtuelle umma'-diskurs, gerne i skarp kontrast til den samfundsmæssige virkelighed, som muslimer møder i diasporaen, og som er kendetegnet ved heterogenitet og intern splittelse (ibid.).

Forholdet mellem det nationale og det transnationale i ummaforestillingen hos DIT er relevant af flere grunde. Masdjid al-Tauba, som Det Islamiske Trossamfunds moske kaldes, besøges og ledes primært af immigranter og efterkommere fra den arabiske verden, og kommunikation med familiemedlemmer og andre aktører i oprindelseslandene spiller stadig en væsentlig rolle i mange af 
organisationens medlemmers liv og dagligdag i Danmark. Ligeledes er imamerne- eller khutabâ ' (sg. khatîb) som prædikanterne rettelig benævnes i islamisk tradition - ofte uddannede fra islamiske institutioner i den arabiske verden. De er uddannede i den arabisk-islamiske verdens traditionelle centre, men bestiger talerstolen i et land i dets umiddelbare periferi. Nogle khutabâ behersker udelukkende arabisk. Desuden er DIT's brug af moderne medier, såsom internettet og dvd'er, til distribuering af khutbaen medvirkende til, at den potentielle gruppe af modtagere indenfor såvel som udenfor landets grænser udvides. DIT's khutbaer distribueres som lydfiler med anført titel, khatîbens navn og dato på organisationens egen webportal ${ }^{1}$, og khutbaerne kan streames, downloades og cirkuleres på andre platforme, ligesom kortere lydklip af taler deles på det sociale medie Facebook.

Ummaen som politisk fallesskab og nationalstatens legitimeringskrise

En hyppigt refereret teori inden for studiet af muslimer og transnationalitet formuleres af Peter Mandaville (2001), som argumenterer for, at globalisering og translokale kræfter bidrager til fremkomsten af en bredere muslimsk offentlighed, der muliggør nye diskurser og understøtter, hvad han kalder en 'genforestilling' (reimagining) af ummaen (Mandaville 2001). Teorien tager sit afsæt i en antagelse af, at transformationer i 'politisk islam', der finder sted i Europa, ikke primært formes på baggrund af forestillinger om Europa eller Vesten i bredere forstand. Fænomener som translokalitet og migration er, ifølge Mandaville, i højere grad med til at forme disse transformationer. Mandaville formulerer en teori om translokal islam som et 'tredje rum':

Translocal Islam is [...] a form of 'third space' or interstitial identity in which the political community of the host society is not accepted or embraced (in terms of configuring one's political identity) but, crucially, neither is that of the cultural 'point of origin', nor its Islam (Mandaville 2001: 105).

Mandaville beskriver forekomsten af traditionelle politiske fællesskaber inden for formelle institutioner, såsom kirke og stat, men, lyder hans tese, politiske fællesskaber skabes i stigende grad også uden for formelle institutioner, hvor staten er ikke længere er den primære kilde til en ønsket forandring og til etisk-poltiske antagelser af, hvad der udgør det gode samfund (ibid.). En parallel antagelse findes i Mark Levines teori om, at nationalstater under globaliseringen lider af, hvad Habermas kalder en legitimeringskrise; dette som konsekvens af fordringer og udfordringer, der stilles nationalstaten fra et flerfold af identiteter eller "neo-fællesskaber" (Levine 2003: 99), der

(C) Forfatteren og Tidsskrift for Islamforskning, ISSN 1901-9580, publiceret 27-4-2012 
ikke har nationalstaten som primær referenceramme. Jeg vil i artiklen argumentere for, at ummaforestillingen i DIT's khutbaer kan anskues primært som et tredje rum, et identitetsfællesskab, hvis antagelser af 'det fælles gode' står i et modsætningsforhold til et nationalt forankret politisk fællesskab. Hvorvidt ummaforestillingen i sig selv kan defineres som politisk, skal jeg vende tilbage til.

\section{Khutbaen historisk - en religiøs eller politisk tale til ummaen?}

Termen khutba refererer på arabisk til en offentlig tale (Wehr 1980: 246), og i en islamisk sammenhæng betegner det en tale, der leveres af en khatîb (taler) fra en ophøjet talerstol (minbar) i en moske ved religiøse højtider og ved den ugentlige fredagsbøn. Den islamiske historieskrivning beretter, at fredagsbønnen (salât al-jum 'a) blev gjort obligatorisk for enhver voksen muslimsk mand efter udvandringen til Medina, hvor Profeten Muhammed fungerede som leder (imâm) af bønnen foruden politisk leder af ummaen. Allerede fra ritualets formative periode var der - foruden udførelse af bøn - tale om en offentlig henvendelse til et afgrænset politisk og religiøst defineret muslimsk fællesskab. Henvendelserne fra den politiske leder - og med tiden dennes guvernører og generaler - knyttede særligt an til anliggender af politisk eller militær karakter (Fathi 1981: 164). Med islams udbredelse og udviklingen af uafhængige islamiske institutioner fik khutbaen en mere religiøs og rituel udformning, og den antog en mere standardiseret form, men op til moderne tid har khutbaen i varierende grad tillige fungeret som medium for politisk kommunikation (ibid.). I islamisk histories første århundreder var denne kommunikation fra den herskende elite særligt udpræget med netop khutbaen som medium, men i den post-klassiske periode bliver khutbaen et oratorisk standardiseret ritual, og prædikanternes rolle som politiske opinionsdannere svækkes (Gaffney 1994: 123). Det politiske indhold i khutbaerne genfindes i mange moderne prædikener i både i form af kritik af det politiske lederskab (Kepel 2003; Gaffney 1994), eller som loyalitetserklæring til de siddende magthavere i moderne nationalstater. Som eksempel på den statslige indflydelse på khutbaen kan nævnes tendensen til, at prædikanter udpeges eller reguleres af den siddende politiske magt. Dette ses i vidt omfang også i moderne muslimske stater, hvor denne funktion varetages af en statslig institution, ofte under ministeriet for religiøse anliggender.

Ligeledes høres et traditionelt fordret imperativ om at tilkendegive loyalitet til den politiske leder i den afsluttende del ('kaldet til de troende', ar. $a l-d u^{\prime} \hat{a}^{\prime} l i-l-m u$ 'minin) af anden del af khutbaen i moderne muslimske lande. 


\section{Khutbaen som kilde til reform af ummaen.}

Den reformorienterede salafiyya-bevægelse i slutningen af 1800-tallet formulerede islam som en rationel og dynamisk religion, der skulle bygge på forfædrenes (al-salaf al-sâlih) 'rene' islam, og repræsentanter for denne bevægelse som Djamal al-din al-Afghani (d. 1897) og Muhammad Abduh (d. 1905) var fortalere for at reformere khutbaen institutionelt, idet de argumenterede for, at den skulle have en opdragende rolle. Khutbaen skulle fungere som politisk instrument for formulering af de nye standarder og værdier, som den nye muslimske umma eller den moderne stat skulle funderes på. Prædikanter skulle lægge de støvede khutbamanualer med temaer om ydmyghed ( $k h u s h u$ '), gudsbevisthed (taqwâ) og eskatologiske advarsler om dommedag ( $w a^{\prime} \hat{\imath} d$ ) på hylden og i stedet give tilhørerne en følelse af socialt ansvar og give dem nyttig information, der kunne gøre dem til aktive samfundsborgere, som ville bidrage til ummaens fremgang. Selv om prædikenerne i det 20. århundrede har haft en mere marginaliseret rolle med introduktionen af medier som aviser, TV, internet (Gaffney 1994: 123), og prædikanterne som konsekvens i bredere offentligheder er marginaliserede som meningsdannere og politiske mediatorer, peger moderne studier af fænomenet - både i sin traditionelle form i moskeen (Gaffney 1994), som digitalt distribueret prædiken (Hirschkind 2006) eller i form af khutbaer afholdt i Vesten (Reeber 1993, 2004; Peter 2006) - at fredagsprædikenen kan have potentiale til social og politisk mobilisering samt fungere som platform for artikulation og produktion af identitet og fællesskab.

\section{Ummaen i khutbaen}

I det følgende vil jeg fremdrage eksempler fra taler, der illustrerer hvordan forestillinger om det globale fællesskab spiller en vigtig rolle i khutbaerne i DIT. Jeg vil tage eksempler fra arabiske imamer, der trods indbyrdes forskellige relationer til Danmark og forskellige oprindelseslande er fælles om at inddrage ummaen som symbolsk katalysator for et ønske om forandring. Fælles er antagelsen, at det ikke er islam som religion, der skal reformeres, kun det muslimske fællesskab. Imamernes formuleringer om reform af ummaen sker med særlig reference til ungdommen, ønsket om enhed og eskatologi. Jeg vil i det følgende illustrere dette med udgangspunkt i khutbaer holdt af DIT's faste khatîb, Muhy Eddin Ouwainat, samt udvalgte gæstekhutabâ' i perioden 2009 til 2011.

\section{Beskrivelsen af ummaens situation}

Den islamiske umma bliver i DIT's khutbaer formuleret i et spændingsfelt mellem moralsk forfald og ophøjet ideal, samt mellem splittelse og enhed. Denne dikotomi resonerer med de moderne 
forestillinger, der har udspring i de tidlige pan-islamiske og salafiyya-inspirerede diskurser, og som vægter deres argumenter på et misforhold mellem det rene, ukorrumperede ideal og den observerbare virkelighed. Realiteternes verdens står ikke mål med idealet, og således er ummaen generelt beskrevet $\mathrm{i}$ et kontrastforhold. I følgende citat høres imamens forundring over, $\mathrm{i}$ hvor ringe grad 'muslimernes situation i dag' harmonerer med imamens idealforestilling om islams universelle gyldighed og moralske overlegenhed:

Kære brødre! Beskueren af muslimernes situation i dag ser og hører noget forunderligt! Han forstår ikke, hvad der er sket med ummaen og med muslimerne. Han står forundret og spørger: "Er dette Islam?” [...] Så spørger han også: ”Er dette Islam som kom til Indien og Kina, til Europa og Spanien, som spredtes til hele verden? Han finder intet svar. Endvidere betragter vi de muslimske mænd og kvinders børn. Vi ser vores sønner og døtre, og vi spørger: "Er disse børn af muslimer?" Stammer disse fra Asma, Aisha og Khadidja? Skændige er muslimernes døtres handlinger! Og muslimernes døtres fremtoning og deres engagement (iltizâm) med Hans metode (manhadj) og den vej som Aisha, Khadidja og Fatima og Asma trådte. Er de børn af muslimer? Stammer de fra Umar, Khaled og Saladdin? (Abu Abdou 30.07.2010, 05:12-07:36).

Denne kritiske tone lyder fra gæstetaleren Muhammed Hamdi Abu Abdou, men forestillingen løber som en rød tråd i de fleste taler i DIT, hvor ummaforestillingen er central. Citatet betoner forestillingen om umma som familie/slægt spredt over hele verden. Det er Profeten Muhammed og de såkaldt ærværdige salaf, der udgør det udtalte ideal i ummaforestillingen. Profeten beskrives af en anden gæstekhatib, Shahed Mehdi, som ummaens eksempel (qudwat al-umma, eks Mehdi 06.03.2009), jævnfør sunna-forestillingen og den Koraniske antagelse af Profeten som det skønne forbillede (uswa hasana, fx Koranen 33:21), og muslimske personligheder igennem historien har været repræsentanter for Profetens metode, særligt i mødet med islams fjender.

Forestillingen om at ummaen er i en forfaldsperiode er særligt udpræget i DIT's khutbaer. Denne opfylder den islamiske reformismes og den pan-islamiske bevægelses credo om at genoplive et tabt fællesskab, og netop dette tabte fællesskab finder sit udtryk i ummaforestillingen. Trods dette forfald opretholder Abu Abdou, Shahid Mehdi og flere af de andre talere i DIT en koranisk 
antagelse af muslimerne som 'den bedste umma' (jf. Koranen 3:10), Guds udvalgte folk. Ummaen er forenet i muslimers fælles tilslutning til trosbekendelsen, som i stedet for den klassiske benævnelse 'shahâda' ofte i khutbaer i DIT kaldes "monoteismens ord" (kalimat al-tawhîd, eks. Abu Abdou 23.07.2010). Ummaen som ideal er knyttet til en forestilling om, at dogmet om den absolutte monoteisme ikke blot er et ord, der skal udtales, men en praksis, der skal udleves. Det muslimske fællesskab er "monoteismens fællesskab" (ummat al-tawhîd, ibid. 4:00f) og Profeten er "monoteismens Profet" (nabî al-tawhîd, ibid.), men foruden denne dogmatiske fordring, vægter imamen i ovennævnte tale Profetens rolle som "enhedens Profet" (nabî al-wihda, ibid.). Ummaens fundament er universelt, og ingen forstod dette bedre end ummaens eksempel, Profeten, som ikke blot i sine ord men i kraft af sine handlinger, udbredte den absolutte monoteisme og forenede de arabiske stammer. Ligesom trosbekendelsen gøres til 'monoteismens ord', gives muslimerne ofte særlige prædikater, når de adresseres i kraft af deres tilhørsforhold til ummaen. De standardiserede tiltaleformer i en khutba ('kære muslimer/kære brødre mv.') bliver eksempelvis af ovennævnte imamer erstattet med "børn af enhedens Profet" (abnâ' nabî al-wihda, ibid.) og "I, der bekender sig til monoteisme" (ayyuhâ al-muwahhidûn, ibid.), jf. den wahhabittiske selvbetegnelse ahl al-tawhîd og ahl al-muwahhidûn. Med dette greb gør imamerne medlemskab af ummaen til noget mere end blot at være muslim. I en anden khutba udtaler organisationens førsteimam, Muhhy Eddin Ouwainat, det mere eksplicit: "Den, der ikke interesserer sig for ummaen, tilhører den ikke" (Ouwainat 18.06.2010, 8:45).

Ummaen i khutbaen refererer som udgangspunkt til summen af alle muslimer, men oftest formuleres den som et særlig moralsk fællesskab, der er karakteriseret ved en betoning af særlige fordrede dispositioner som ret rituel observans, renhed og tålmodighed hos den enkelte muslim. Det forhold at muslimen ikke blot bekender sig til - men praktiserer - monoteismen danner fundamentet for "ummaens storhed, styrke, videnskab og fremgang" (Abu Abdou 23.07.2010, 04:43f) og, fortsætter imamen, Profetens bevidsthed om dette skabte den perfekte enhed i dogme såvel som organisation. Profetens eksempel demonstrerer, at "ummaen siden den dannedes har været en bestræbelse mod enhed" (ibid. 7:25), og imamen læser varsler om den interne splittelse i ummaen i Koranen 8:46 (ibid. 9:47f). Mens nogle imamer særligt taler om splittelse som et fænomen blandt muslimer i Vesten, er det dog klart, at det er hele den globale umma, der lider af denne fragmentering. I Vesten kommer splittelsen til udtryk i manglende rituel, dogmatisk og organisatorisk enhed: 
Vi er Vesten. Skændigt er det, at vores hjerter, dogmer, række, bøn, 'îd-fejring og fredagsbønner (jum'atunâ) ikke er én. Vi ser forskellige fredagskhutbaer, 'îd-fejringer på forskellige tidspunkter og vores ramadan... det ene sted faster man i dag, et andet sted i morgen! Hør, monoteismens umma, kaldets umma! Ihukom det, Muhammed bragte frem: Enhed og monoteisme. Disse kan ikke skilles ad! Kære brødre, vi opfordrer ikke til enhed baseret på modsætninger - den ene er egypter, den anden er jordaner, den tredje er marokkaner, den ene fra syd, den anden fra nord. Nej, vi kalder til en enhed med rum til alle nationaliteter og farver. I skal alle være som ét hjerte! ('alâ qalb wâhid) (Abu Abdou 23.07.2010, 12:18f).

Her taler imamen direkte fra sin minbar til ummaen som helhed, ikke blot til den tilstedeværende menighed. Ummaen påkaldes som symbol på en fordring om enhed, forandring og fremgang. Med reference til Koranen 4:59 ${ }^{3}$ genkalder imamen budskabet om, at muslimer "ikke skal strides om det der er mellem dem, men gå til dommen (al-hukm)" (ibid. 14:45), hvormed forstås Koranen. I manglende efterlevelse af dette ser man, at muslimer fraktioneres:

Det, der splitter ummaen i dag, er egenkærlighed, kærlighed til laster, orientering mod det dennesidige (rukûn ilâ al-dunyâ) og kærlighed for lederskab og positioner. På mine ture til europæiske moskeer har jeg set fjendskab mellem muslimer. Årsagerne er så mange, de ikke kan nævnes! Nogle ønsker etnisk enhed ('irqîya), nationalisme (watanîya), regionalisme, ja selv fraktionalisme (hizbîya)! Den ene er ikhwânî, den anden er salafî, den tredje er hizb ut-tahrîr, den fjerde er tablîghî... ${ }^{4}$ Dette er den største katastrofe, der er hændt muslimerne! Saml jer om monoteismens ord! (Abu Abdou 23.07.2010, 17:45f)

Imamen oplever, at ummaen i Danmark og Europa er karakteriseret ved muslimer, der af egeninteresse bestræber sig på at repræsentere 'den muslimske minoritet' og besidde 'poster'. Som konsekvens heraf foreslår imam Abu Abdou, at muslimer i Danmark samles under et fællesskab med én leder: "en ren mand, hvis mål er ummaens enhed" (ibid., 21:34) og "én imâm" (ibid. 24:50). Dette kan afhjælpe uenighed af rituel karakter, eksempelvis om afholdelse af ramadân og 'îd-fester. Ligeledes bør der, i følge imamen, kun være én fredagskhutba i København, der kan samle og 
repræsentere alle muslimer i landet. Kravet om en styrket umma og om organisatorisk enhed nationalt såvel som transnationalt er dog sjældent knyttet til særlige politiske fordringer i DIT.

Ummaen bliver et potent symbol i taler, der vægter islams universelle karakter og religionens afterritorialisering. Profetens 'umma'-eksempel som missionær for hele menneskeheden og som samlende kraft skal, ifølge flere af DIT's imamer, genoplives blandt muslimer i Vesten, således at ummaens sande kvalitet kan aktiveres. Det er en stadig kilde til kritik blandt imamerne, at muslimerne ikke er bevidstgjorte om denne universalisme, og eksempelvis bemærker Abu Abdou, at man alt for ofte ser muslimer, som tager særlige ikke-islamiske, regionale praksisser og "barbarisk stammementalitet" ('asabîya jâhilîya, ibid. 28:00) med til destinationslandet, når de krydser grænser. Jævnfør citatet ovenfor er det ikke en 'renere' islam, der praktiseres i ummaens center (de muslimske lande), men muslimerne konfronteres i højere grad med ummaens fragmentariske karakter i diasporaen pga. muslimernes varierende ophav, gruppedannelser og flerfold af traditioner og praksisser. Årsagen til ummaens tilstand af splittelse findes ikke primært i ydre, politiske rammer eller i konfrontation med Vesten, men i det formulerede faktum at de enkelte muslimer ikke er 'som én mands hjerte' i dogme og handling. I fravær af det gode eksempel vokser den muslimske ungdom op uden retningsmarkør, og de forfalder til dekadence, lyder imamens kritik.

\section{Den ideologiske forskydning i DIT's khutbaer}

I taler af DIT's tidligere førsteimam, den kontroversielle Ahmed Abu Laban (d. 2007), kunne man i høj grad høre formuleringer om ummaen som et politisk fællesskab, hvor lederskab og politisk organisation var centrale for den fordrede enhed. Det muslimske fællesskab var "lederskabets umma" (ummat al-qiyâda, Abu Laban 06.01.2006, 27:00) og knyttedes til antagelser af "politik" (siyâsa, ibid. 17:15) og direkte engagement med nationale politiske dispositioner og institutioner. Dette synes at have ændret sig efter imamens bortgang, der resulterede i, at den egyptiskfødte og alAzhar uddannede imam Muhy Eddin Ouwainat efter en overgangsperiode blev DIT's førsteimam. Dette markerer en ideologisk forskydning i synet på måden, hvorpå forandring afstedkommes i ummaen. Mens Abu Laban repræsenterede en klassisk islamisme, der vægtede politisk og organisatorisk aktivitet som grundlag for forandring på nationalt niveau, er Ouwainat samt flere af DIT's seneste gæsteimamer repræsentanter for en mere moralsk funderet salafisme; dette i den 
forstand at den fordrede forandring først og fremmest forventes at ske gennem individets reform, ikke via politisk konfrontation med danske nationalstatslige aktører.

Et hyppigt tilbagevendende tema hos alle imamerne på tværs af ideologiske skel er ungdommens rolle i den fordrede forandring. I arabiske khutbaer i Københavnske moskeer hører man ofte antagelser af en 'afvigende' (munharif) ungdom, og at dette er en trussel for det muslimske fællesskab og for ummaens sikkerhed. Dette er en udbredt forestilling om ungdommen, som tilmed høres i standardiserede khutbaer, der blot er reproduktioner af tilgængelige khutbaer på internettet 5 . Men mere interessant i denne sammenhæng er det at betragte forskelle i de positive formuleringer, der gøres gældende om ungdommen i DIT's khutbaer, da dette ligeledes afspejler den anførte ideologiske forskydning. Abu Laban fremhævede den del af den muslimske ungdom, som var organisatorisk aktiv i opbyggelsen af 'det islamiske projekt' i Danmark med henblik på at oprette en "islamisk stat" (Abu Laban 31.03.2006, 45:00f). Kravet om forandring hørtes hos Abu Laban ofte formuleret i en national dansk kontekst. Unge medlemmer af DIT fremhævede han for deres konfrontation med danske nationale politikere, idet de unge var gode eksempler på islamisk lederskab. Ligeledes sås et tydeligt politisk engagement med internationale statslige aktører, politikere og institutioner, i forhold til hvilket kravet om forandring artikuleredes. I det følgende afsnit skal vi se, hvorledes ungdommen som kilde til forandring i ummaen formuleres anderledes af DIT's nuværende førsteimam. Det ligger ikke inden for denne artikels ramme at forklare årsagen til denne udvikling, da man fra organisationens side ikke har ønsket at kommentere på bestyrelsesanliggender. Personlige samtaler med medlemmer af organisationen peger dog på, at der til grund for ansættelsen af den unge imam Ouwainat bl.a. lå et udtalt ønske, særligt i DIT's ungdomsorganisation Munida, om ansættelse af en mere lærd imam med uddannelse fra et velrennomeret islamisk universitet. De tidligere førsteimamer, Ahmed Abu Laban og Mustapha Chendid, var ikke i besiddelse af et uddannelsescertifikat fra et islamisk universitet. Netop det forhold at Ouwainat er uddannet fra al-Azhar universitetet fremhævedes af flere medlemmer, jeg talte med, som grundlag for at hævde imamens - og organisationens - særlige religiøse autoritet. Hvorvidt ansættelsen af imamen er udtryk for et bevidst ønske om en anderledes ideologisk profil er uvist, men det er værd at bemærke, at også mange af DIT's seneste gæstekhutbâ' deler Ouwainats ideologiske kendetræk, som vil blive uddybet i det følgende. 
Jeg vil tage udgangspunkt i Ouwainats khutba 'Forandringens begivenheder' (ahdâth al-taghyîr) afholdt d. 18.02.2011, og som er et led i en række khutbaer om de folkelige opstande i arabiske lande. I alle talerne om emnet findes et tema, som udfoldes til fulde i 'Forandringens begivenheder', nemlig forklaringen af den bagvedliggende kilde til forandring i den islamiske umma.

\section{Ungdommen og 'Forandringens begivenheder', februar 2011.}

I denne khutba, der afholdes fredagen efter afsættelsen af den egyptiske præsident Hosni Mubarak, udtrykker Ouwainat en bevidsthed om, at den følelse af sejr, som han giver udtryk for i khutbaen, deles af hele den islamiske umma. Imamen går direkte til emnet i en introduktion, der genkalder temaet fra de forrige khutbaer:

Brødre, vi lever stadig med disse nye begivenheder, som begejstrer vores arabiske og islamiske umma. Vi lever stadig i glæde over denne klare sejr for vores folk $(a h l) \mathrm{i}$ Tunesien og Egypten, og vi venter stadig på Guds sejr for resten af vores lande, at deres lænker brydes, at sejren realiseres for dem, at retfærdighedens vægt indføres, at Gud bringer retfærdigheden tilbage til sit folk, og at Gud tager hævn over tyrannerne (al-zâlimîn). I disse begivenheder er der flere lektioner og advarende eksempler, som vi alle kan drage nytte af (Ouwainat 18.02.2011, 06:14 - 07:54).

Imamen taler i førsteperson pluralis som medlem af ummaen. Hvori det 'advarende eksempel' findes, forklarer imamen som følger:

Vi har ikke bragt noget frem, vi har ikke båret våben, vi har ikke arbejdet ud fra en strategi. Kun gennem vores unge, rene muslimske mænd kom den klare sejr fra Gud. Derfor påhviler det os, mine brødre, ikke at glemme vores Herre i sejrens rus. I sejrens rus skal vi erindre Gud og takke Ham, Han være ophøjet. ’Ihukom Mig! Så vil Jeg ihukomme jer. Vær Mig taknemmelige, og vær ikke vantro! (Koranen 2:152)" (Ouwainat 18.02.2011, 09:16 - 9:47).

Denne tak for guddommelig intervention i form en tyrans (zâlim) detronisering, skal muslimer udtrykke ved prostration (sudjûd), dvs. gennem bønner til Gud, erfarer man videre (ibid. 10:12). Muslimerne skal i denne forbindelse ihukomme Guds intervention 
ved det historiske slag ved Badr i år 624, hvor Profeten Muhammeds hær, i følge islamisk tradition, med Guds assistance sejrede over Quraishstammen, da begge begivenheder repræsenterer den samme kosmiske kamp. Parallellen mellem slaget ved Badr og kontemporære oprør i mellemøstlige lande findes i det forhold, at renhed formuleres som en forudsætning for, at Gud giver sejr. Imamen spørger retorisk, hvor mange "demonstrationer og protester", der ikke er holdt i "vores lande" (ibid. 12:33), underforstået mange. Det er således ikke den sociale bevægelse, som demonstrationerne repræsenterer, der skaber forandringen. Det forhold at sejren kommer på dette tidspunkt, lærer Koranen, er betinget af, at den rette tilstand, en renhed, er opnået hos folket - her repræsenteret af 'de rene unge mænd'. En tilstand, der bevirker at Gud kan - hvis han ønsker det - generere forandring og vælte tyranner.

Andre gældende fortolkninger af begivenhederne og folkets motivation til konfrontation afviser imamen i det følgende citat, hvor han i forlængelse af referencen til slaget ved Badr benævner aktører i begivenhederne, som deltagere en militær kamp:

Vores brødre i Tunesien, Egypten - og i dag i Yemen - såvel som andre lande [...] har kun ét ønske. De ønsker ikke ophøjethed på jorden, og ikke fordærv, men de ønsker at repræsentere sandhedens soldat i konfrontationen med urettens soldat. De ønsker at sandheden sejrer, om blot med ord. De ønsker at støtte sandhedens folk (ahl al-haqq), og de venter på Gud for deres sejr, deres støtte og styrke. Disse folk forsvarer os, kære forsamling! [...] Disse, der stod i ummaens frontrække (tâli'at al-umma) (ibid. 14:21 $15: 40)$.

Imamens viden er ikke bygget på aktørers egne udsagn i medier eller referencer til personlige samtaler, men imamen parafraserer Koranen 28:83 i beskrivelsen af 'brødrenes' (oprørernes) ønske ("de ønsker ikke ophøjethed på jorden, og ikke fordærv"). Det er et koranisk eskatologisk udsagn om de folk, der skal få en plads i paradis, der udgør imamens reference og forståelse af demonstranternes motivationer og krav. Aktørerne kæmper for den muslimske nation og således også for den enkelte muslim i menigheden i Københavns nordvestkvarter. At konkurrerende udsagn eksisterer i offentligheden og i medierne, der udfordrer denne fremstilling af begivenhederne, anes i det følgende:

(C) Forfatteren og Tidsskrift for Islamforskning, ISSN 1901-9580, publiceret 27-4-2012 
Tro ikke det er nationalisme eller patriotisme! Nej, min bror. Nej, det er sandhedens revolution i mødet med uretten! Ja, det er islams revolution $\mathrm{i}$ konfrontationen med uret og tyranni (Ouwainat 18.02.2011, 15:15f)

Konfrontationens domæner er 'islam' og de koraniske termer 'zulm' (uret) og 'tughyân' (tyranni); termer som i islamistisk diskurs har fået en fornyet anvendelse til fordømmelse af muslimske ledere, hvis regeringsførelse anses for u-islamisk, men konfrontationen formuleres ikke med anvendelse af moderne politisk terminologi. Ligeledes nævner imamen ikke navne på politiske aktører. Dette holder dog ikke taleren fra at lufte forestillinger om lederskab og herredømme i islam. At besidde 'herredømme' (mulk) er, i følge imamen, ikke noget mennesket selv vælger, hvad enten det er nutidige regenter, eller det er Koranens Farao eller Nimrod. Det er altid en konsekvens af Guds vilje, og tilegnelsen af herredømme har karakter af en "test” (ibid. 17:29). Dette forhold "belærer muslimerne om ikke at stræbe efter at være præsident, ikke at stræbe efter magt (sulta), herredømme, eller efter at være leder eller konge" (ibid. 17:34 - 17:48). Regenten vil blive stillet til ansvar for sin varetagelse af embedet på dommedag. Det ideelle eksempel på en leder gives i en hadîth om Umar ibn al-Khattab, som repræsenterer retfærdighedsbevidsthed og bevidsthed om det endelige regnskab (ibid. 18:25 - 19:10). Denne ideelle forestilling om lederskab sættes i talens sidste del i skarp kontrast med de forhold, der længe har hersket i de muslimske lande:

\footnotetext{
Dette er det modsatte af, hvad vi ser i vores lande, mine brødre! Modsat ser vi denne konkurrence. Folk strides om at blive medlemmer af repræsentative forsamlinger, af ministerier, regionale råd $\mathrm{og} \mathrm{om}$ at besidde forskellige administrative poster. De ønsker at besidde poster, fordi folkets tro (imân) er svag. Det får dem til at glemme deres position foran Gud på dommens dag (Ouwainat 18.02.2011, 19:50 - 20:00).
}

Muslimske regenter fremdrages som repræsentanter for denne udvikling. De har glemt Gud, og Satan "ornamenterer deres gerninger" (ibid. 20:56). De gode kræfter, der findes i landene skal besidde positioner i overensstemmelse med 'Guds ønske', men hvorledes denne proces skal finde sted interesserer ikke imamen i khutbaerne (ibid. 22:11 - 22:30). Ønsket om at besidde politiske poster begrundes i svag tro og manglende ihukommelse af

(C) Forfatteren og Tidsskrift for Islamforskning, ISSN 1901-9580, publiceret 27-4-2012 
dommedag. Imamen genkalder en hadîth, der beskriver den islamiske ummas situation samt årsagen til den forestående forandring:

I husker måske hadîthen, hvor Profeten siger: "Der vil komme en tid, hvor nationerne (al-umam) vil omringe jer fra alle sider ligesom [man samles om] mad i en kedel" De spiser jer, de spiser jeres penge, og de spiser jeres gode ting. De er nationernes bytte. "De sagde: er det fordi vi er et fåtal? Han sagde: nej, men I er afskum som afskum på en flodbølge". Et stort antal, men uden effekt! Et stort antal, som ikke har værdi (qîma) eller tyngde (wazn)! "Og frygt vil fjernes fra jeres fjenders hjerter, og svaghed vil vore i jeres hjerter". Svaghed! "Han sagde: på grund jeres kcrlighed til verden og had til døden!" Kærlighed til verden og had til døden, som muslimerne i disse lande giver efter for! Den dag tilstanden vendes, elsker folk døden og hader verden! Hvad sker der så? Så ændres tilstanden. ”Gud ændrer ikke noget i folk, førend de ændrer, hvad der er i dem selv" (Koranen 13:11) (Ouwainat 18.02.2011, 33:12 -34:18).

Forandring i ummaen afstedkommes gennem individets reform. De 'unge mænd', der står i 'ummaens frontrække' som 'soldater', har deres tro og kærlighed til døden som våben, ikke en politisk strategi eller organisatorisk forankret aktivisme. Derved realiseres den ovenfor citerede sura (Koranen 13:11), hvis centralitet bekræftes ved, at den gentages tre gange i khutbaen. Ligesom det var tilfældet i Abu Abdous khutba om reform af ummaen, knyttes den fordrede dogmatiske enhed til frasen om at folket skal blive som 'én mands hjerte':

Hvad kom de [rene unge mænd] med? For det første var folket som én mands hjerte ('alâ qalb rajul wâhid), og dette er en af sejrens grundlæggende søjler, ordets sammenkomst (idjtimâ' al-kalima), rækkens enhed, fællesskab og et godt greb i Guds reb (habl allâh) (ibid. 27:07- 27:34).

Hjertet bliver metafor for enhed $\mathrm{i}$ ord, handling og religiøs orientering, og den koraniske frase 'at holde fast i Guds reb' knytter ligeledes an til kravet om enhed i muslimernes tilknytning til Gud. Det er ikke en organisatorisk enhed, der skaber forandring i Ouwainats khutba, men en religiøs enhed, som fordres i Koranen.

(C) Forfatteren og Tidsskrift for Islamforskning, ISSN 1901-9580, publiceret 27-4-2012 
I khutbaen hylder imamen den demonstrerende ungdom, men det er bemærkelsesværdigt, at imamen ikke engagerer sig i de krav, der gøres gældende af disse politiske aktører. Det er ikke de unges politiske eller revolutionære potentiale til at gennemtvinge økonomiske eller politiske forandringer i en national egyptisk eller tunesisk sammenhæng, som imamen priser, men ungdommen gives stemme af koraniske narrativer, der reflekterer dikotomien mellem den guddommelige og menneskelige magt. De politiske revolter tages ud af deres nationalstatslige politiske kontekster og gøres til ‘islams revolution’, en på samme tid mytologisk og konkret kamp for den muslimske umma. Talen 'Forandringens begivenheder' er et eksempel på Ouwainats bestræbelser på - her med lån af et citat af Roel Meijer - at "handle a-politisk i en politisk verden" (Meijer 2009: 17). Reform og forandring gennem individets rituelle og dogmatiske renhed spiller en større rolle i imamens khutbaer end politiske begreber som sharî'a og siyâsa, hvilket karakteriserer en ummaforståelse inspireret af en moralsk funderet, apolitisk salafisme. Dette skal ikke forstås således, at politiske udtryk er helt fraværende i imamens khutbaer (eksempelvis ordet 'grundlov' i det følgende citat), men det særligt salafistiske findes i den hyppige vægtning af moralske, rituelle og eskatologiske faktorer som katalysator for reform og forandring snarere end politiske ditto.

\section{Ummaen i diasporaen}

Jeg har tidligere anvendt termen diaspora til at betegne et træk ved muslimers tilstedeværelse i Danmark, og en afklaring af termen er her på sin plads, da ordet ikke anvendes traditionelt $\mathrm{i}$ betydningen af et spredt etnisk eller nationalt fællesskab. Jeg anvender ordet inspireret af Pnina Werbners (2002) definition af diasporafællesskaber som "communities of co-responsibility" (2002: kap. 10). Imamernes formuleringer om ummaen og menighedens relation hertil indebærer en klar fordring om loyalitet og tilkendegivelse af eksistentielle samhørighed med disaporafæller på tværs af nationale grænser. Denne term synes bedre at passe til de antagelser, som gøres gældende i khutbaerne, end den mere sociologiske betegnelse 'minoritetsfællesskab', da det ikke er de danske muslimernes egenskab af social eller religiøs minoritet, der fremhæves i talene, men netop deres relation til andre muslimer over hele verden. Hvad angår spørgsmålet om, hvad diasporasituationen betyder for forståelsen af ummafællesskabet, samt at muslimer i Danmark udgør en minoritet, er Ouwainats khutbaer præget af et tydeligt behov for at formulere, hvem

(C) Forfatteren og Tidsskrift for Islamforskning, ISSN 1901-9580, publiceret 27-4-2012 
muslimerne er, hvad der kendetegner dem som muslimer i relation til det omgivende samfund og hvilke fordringer, der påhviler dem som muslimske immigranter i Vesten.

Det omgivende samfund beskriver Ouwainat som en "ateistisk civilisation" (hadâra mulhida, 29.2.2008, 30:18), der er fattig på åndelighed og moral. Muslimer skal ikke skjule deres anderledeshed i forhold til det omgivende samfund, men klart udtrykke det:

Sig - og jeg siger det - med styrke og ikke med svaghed i stemmen, ikke som propaganda, men som sandhed (kalâm al-haqq): "Vi ønsker sandheden, vi ønsker retfærdighed! Jeg er muslim! Min grundlov (dustûrî) og min metode (manhajî) er Guds bog. [...] Mit folk (ahl) er den muslimske nation - de er mit parti (hizb) og Guds parti! (Ouwainat 04.04.2008, 27:46-28:16).

Muslimer beskrives som anderledes end 'danskere' (ahl al-danimark) i kraft af deres tilhørsforhold til den islamiske umma, ikke som marginaliserede etniske eller sociale kategorier. Ouwainat beskriver ligeledes islam som i konflikt med både "Østen og Vesten", som ikke forstår muslimernes "budskab" (29.02.2008, 35:07). Østen og Vesten er geografiske kategorier, mens islam er et moralsk og religiøst system, der ikke er knyttet til en særlig geografi. Ummaen kender ingen grænser:

Gud giver dig - og han giver hele denne mægtige umma - stråler af lys, som lyser vejen op for dig. Oh umma! Vær ikke bedrøvet! Du er den udvalgte, som Gud beskrev skal bære dette klare lys til verden! (ibid. 07:40-08:04) [...] I er den umma, som Gud har foreskrevet det evige liv (ibid. 13:58-13:41).

Ligesom som tilfældet $\mathrm{i}$ talen om det arabiske forår giver imamen ungdommen, som ofte beskrives som ‘anden generation', særlig opmærksomhed i kraft af dens ansvar for at udbrede 'det klare lys' til det omgivende samfund, som de er vokset op i og derfor ofte kender bedre end deres forældre og imamen selv. Ungdommen er i Ouwainats khutbaer om muslimer i Vesten knyttet til ummaens fremgang, som tilfældet er i de muslimske lande. Minoritetssituationen bevirker, at behovet for mission aktualiseres og bliver en særlig fordring knyttet til ummaen. Selvom det danske aspekt af ummaen ikke får meget

(C) Forfatteren og Tidsskrift for Islamforskning, ISSN 1901-9580, publiceret 27-4-2012 
opmærksomhed i Ouwainats khutbaer, er det tydeligt, at imamen ser et potentiale for udvidelse af ummaen gennem ungdommens moralske eksempel.

\section{Nationen og spørgsmålet om loyalitet.}

Som tidligere nævnt har der været tradition for, at imamem tilkendegiver loyalitet til den nationale politiske leder i de afsluttende invokationer ( $\left.a l-d u^{\prime} \hat{a}\right)$ i khutbaen. Menighedens egenskab af diasporafællesskab, gør det relevant at stille spørgsmålet, hvilken karakter disse loyalitetserklæringer antager i diasporaen, eller om de helt udelades. Hos DIT's nuværende imamer er der ingen nationalpolitiske loyalitetserklæringer at spore, men de indeholder derimod ofte afsluttende invokationer til Gud om at styrke ummaen i konfrontationen med 'Guds fjender'. Denne mytologiske kamp gives i visse khutbaer konkret udtryk i ønsket om sejr i "de kæmpendes lande" (bilâd al-mudjâhidîn, eks. Ouwainat 04.04.2008, 33:50) i lande som Irak, Palæstina, Afghanistan, Somalia og Tjetjenien. Ligesom den klassiske loyalitetserklæring til den politiske ledelse i Danmark eller i eventuelle muslimske oprindelseslande er fraværende i DIT's khutbaer, er ønsker om kalifatet som politisk ramme for ummaen også fraværende i khutbaerne, omend kalifatet kan høres som nostalgisk referenceramme (eks. Mehdi 11.06.2010, 23:23). Dette betyder ikke at tilhørsforholdet til ummaen i diasporasituationen ikke giver anledning til særlige overvejelser om loylitetskonflikter. I forhold til de (primært arabiske) hjemlande hører man ofte disse benævnt i khutbaerne som 'fædreland' (watan), mens livet i Danmark eller Vesten høres betegnet som en tilstand af udlændighed (ghurba) - dette selv blandt khutabâ' som har været i Danmark en årrække. Som det antydes $i$ et af de tidligere citater af Ouwainat, er forestillingen om, at specifikke nationer eller nationale fællesskaber gør krav på muslimers loyalitet tilstede. Men disse nationale fællesskaber, der (med Palæstina som en undtagelse) er knyttet til nationalstater, er dog ikke genstand for megen interesse i khutbaerne. Tilhørforholdet til ummaen er primært formuleret som et medlemskab af et særligt moralsk og religiøst fællesskab, der ikke fordrer en særlig politisk loyalitet.

Loyalitet formuleres således ikke direkte i politiske vendinger, og det er overvejende på det moralske, religiøse og identitetsmæssige plan at konfrontationen med konkurrerende - og evt. parallelle - fællesskaber forankres. I en khutba af en af DIT's mange gæsteimamer fra 2010, Muhammad Tojkani, bliver loyalitetstilkendegivelsen dog eksplicit formuleret - ikke i en afsluttende invokation men som et emne, der behandles direkte i khutbaen i relation til ungdommen. 
Idealet i Tojkanis khutba er en ung mand, der ikke lader sig påvirke af "politik" (Tojkani 02.04.2010, 14:00):

Sådan en ung mand ønsker vi! [...] Du skal være muslim. Din forpligtelse og din identitet (huwîyatuk) er hos islam! Din nationalitet (djinsîyatuk) og din etnicitet ('irqîyatuk) er islam. Fordi du er søn af islam. Selvom du er muslim, er du også en muslim, der er søn af det land du bor i. Vi ønsker, at du er søn af landet (ibn al-balad) med din krop og i dine papirer, men vær muslim i din loyalitet (walâ'ik) og dine dogmer, sæder og moral! Dette er den unge, som kan være et eksempel for det samfund, han lever i! (ibid. 15:32f)

Her sætter imamen ord på (mis)forholdet mellem tilknytningen til watan (fædrelandet) og umma, og han forklarer, hvorledes muslimer i diasporaen bør navigere i disse felter. Hvorledes 'loyalitet' skal forstås, fremgår ikke klart af khutbaen, men forestillingen om, at muslimer er knyttet til eksempelvis den danske stat (jf. 'papirer') via kroppen, resonerer med den i flere khutbaer udtalte antagelse af, at muslimer bosiddende i Vesten - i ikke-islamiske lande - indgår i en sikkerhedspagt ('aqd amân) med modtagerlandet og følgelig er forpligtet til at følge den gældende nationale lovgivning og indrette sig efter de dertil hørende politiske institutioner. Dette er kroppens og papirernes domæne. At muslimer i Vesten på den anden side er moralsk og religiøst forpligtet til en konkurrerende loyalitet er tydeligt. Ligesom forandring ikke knyttedes til antagelser af det politiske (siyâsa) hos Ouwainat, er loyalitet i citatet af Tojkani ikke at finde i det politiske domæne; loyalitet ift. ummaen knyttes til dogmatisk enhed og moral.

\section{Afslutning: Umma som værn mod assimilation?}

Resistance to assimilation can take the form of reclaiming another nation that has been lost, elsewhere in time and space, but that is powerful as a political formation here and now (Clifford 2006: 452, 1. 2-3)

James Cliffords ovenstående antagelse om diasporakulturer i almindelighed indkredser den funktion, den muslimske umma antager i de arabiske khutbaer hos DIT. Bekræftelsen af den særlige muslimske identitet sker ved, at imamen understreger muslimers fælles tilknytning til den islamiske umma, samt beskriver det muslimske moralske fællesskab i et modsætningsforhold til det

(C) Forfatteren og Tidsskrift for Islamforskning, ISSN 1901-9580, publiceret 27-4-2012 
omgivende sekulære samfunds normer og moralske standarder. I påberåbelsen af dette tilhørsforhold er der, jf. citatet af Clifford, en klar tilkendegivelse af en modstand mod assimilation i forhold til et nationalt fællesskab. Khutbaen i DIT synes at understøtte den vigtige funktion at skabe fællesskabsbevidsthed og solidaritet med et globalt defineret fællesskab - i opposition til et nationalt defineret fællesskab. Disse ummaforestillinger deler ligheder med Mandaville og Levines teorier om translokal islam som en 'interstitiel' identitet, der ikke er knyttet til særlige forestillinger om nationalstaten som kilde til antagelser af det gode samfund eller som den primære kilde til forandring. Hvis Cliffords udsagn skal harmonere med ummaforestillingerne i DIT, er det dog relevant at definere, hvad der menes med 'political formation'. Her kan Mandavilles brede definition på 'politisk fællesskab' tages i anvendelse. Dette beskriver Mandaville som: “a system composed of a set of ethical claims and its subject constituency, both of which who are to some extent predicated on one another" (Mandaville 2001: 11). Med denne definition på politisk fællesskab som centreret om etiske fordringer snarere end institutionaliserede procedurer samt nationalstatslige rammer for udøvelse af politik som parlamenter og valg, kan det formulerede ummafællesskab i DIT's khutbaer karakteriseres som politisk. De gennemgåede khutbaer har netop illustreret, at politisk aktivitet $\mathrm{i}$ traditionel forstand med nationalstaten som ramme og politiske partier som organ for forandring ikke betragtes af imamerne som et middel til reform af ummaen. Omvendt er muslimers higen efter politiske 'sæder og positioner' formuleret som et tegn på splid i ummaen og blandt de mindre eskatologiske tegn på de sidste tider. I overensstemmelse med hvad jeg kaldte imamernes tilsyneladende påvirkning fra en apolitisk, moralsk funderet salafisme, bliver forandring og fremgang i ummaen i khutbaerne i DIT knyttet til individets reform, rituel renhed og dogmatisk enhed.

\section{Referencer}

Allievi, Stefano, 2003: "Islam in the Public Space”, In: Stefano Allievi og Jørgen S. Nielsen (red.): Muslim Networks in and across Europe, Leiden, Brill. S. 1-28.

Clifford, James, 2006: “Diaspora”, In: Ashcroft, B: Griffiths, G.; Tiffin, H. (red.): The Post-Colonial Studies Reader, New York, Routledge. S. 451-455.

Denny, F.M., 2012: "Umma." Encyclopaedia of Islam, Second Edition, Det Kongelige (C) Forfatteren og Tidsskrift for Islamforskning, ISSN 1901-9580, publiceret 27-4-2012 
Bibliotek Copenhagen.

http://referenceworks.brillonline.com.ep.fjernadgang.kb.dk/entries/encyclopaedia-ofislam-2/umma-COM 1291

Fathi, Asghar, 1981: “The Islamic Pulpit as a Medium of Political Communication”, in: Journal for the Scientific Study of Religion, Vol. 20, nr. 2: 163-172.

Gaffney, Patrick, 1994: The Prophet's Pulpit. Islamic Preaching in Contemporary Egypt, Berkely, University of California Press.

Hirschkind, Charles, 2006: The Ethical Soundscape. Cassette sermons and islamic counterpublics, New York, Columbia University Press.

Kepel, Gilles, 2003: Muslim Extremism in Egypt, the prophet and pharaoh, Berkeley, University of California Press.

Levine, Mark, 2003: "Human Nationalisms" versus "Inhuman Globalisms", In: Stefano Allievi og Jørgen S. Nielsen (red.): Muslim Networks and Transnational Communities in and Across Europe, Leiden, Brill. S. 78-127.

Mandaville, Peter, 2001: Transnational Muslim Politics. Reimagining the Umma, London, Routledge.

Meijer, Roel (red.), 2009: Global Salafism, London, C. Hurst \& Co. 
Peter, Frank, 2006: "Islamic Sermons, Religious Authority and the Individualization of Islam in France”, In: M. Franzmann, C. Gärtner og N. Köck (red.): Religiosität in der säkularisierten Welt, Wiesbaden, VS Verlag.

Reeber, Michel, 2004: 'La prédication (khutba) dans les mosquées en France et en Europe”, In: J. Joncheray \& P.J. Luizard, M. Cohen. (red.) Les transformations de l'autorité religieuse, Paris: L'Harmattan. S. 187-198.

— 1993: "Islamic preaching in France: Admonitory addresses or a political platform?" in: Islam and Christian-Muslim Relations, vol. 4, no. 2: 210-222.

Roy, Olivier, 2007: Secularism Confronts Islam, Columbia University Press E Book.

Schulze, Reinhard, 2002: A Moderne History of the Islamic World, New York, I.B. Tauris og Co. Ltd.

Wehr, Hans, 1980: A dictionary of modern written Arabic, Beirut, Libraire du Liban.

Werbner, Pnina, 2002: Imagined Diasporas Among Manchester Muslims: The Public Performance of Pakistani Transnational Identity Politics, World Anthropology, Oxford, James Currey.

Wulff, Ellen, 2006: Koranen, København, Forlaget Vandkunsten.

\section{Citerede khutbaer fra DIT. Tilgangelige på www.wakf.com:}

Abou Abdou, Muhammed Hamdi, 30.07.2010: aina al-khalal?

- 23.07.2010: al-tawhîd asâs al-wihda

Abu Laban, Ahmed, 06.01.2006: al-mashru' al-islâmî

- 31.03.2003: al-mu'tamarât bayn al-tawsîyât wa al-tawaqqu'ât

(C) Forfatteren og Tidsskrift for Islamforskning, ISSN 1901-9580, publiceret 27-4-2012 
Mehdi, Shahed, 06.03.2009 al-'ibra min al-umam al-sâbiqa

Ouwainat, Muhy Eddin, 18.01.2011: ahdâth al-taghyîr

- 18.06.2010: qawâfil kasr al-hisâr

- 04.04.2008: lâ tankasir

- 29.02.2008: al-jazâ' min jins al-'amal

Tojkani, Muhammad, 02.04.2010: risâla ilâ al-shabâb

\section{Om forfatteren}

Andreas Lysholt Mathiasen er cand. mag. i Arabisk Sprog og Mellemøstlige Samfundsforhold fra Københavns universitet og har beskæftiget sig med islamisk prædiken i den arabiske verden såvel som i Danmark. Passager i artiklen er uddrag fra specialet "Fredagskhutbaen mellem religiøs mission og politisk kritik" (2011).

\footnotetext{
${ }^{1}$ Se www.wakf.com. Under 'mediebibliotek', vælg 'khutba'

${ }^{2}$ Koranen 8:46: "Adlyd Gud og Hans udsending! I skal ikke strides med hinanden [...]"

${ }^{3}$ Koranen 4:59: " I, som tror! Adlyd Gud! Adlyd Udsendingen og dem blandt jer, der har myndighed! Hvis I strides om noget, så fremlæg det for Gud og Udsendingen, hvis I da tror på Gud og den yderste dag! Dette er bedre og giver det smukkeste udfald

${ }^{4}$ Disse arabiske termer fungerer som betegnelser for medlemmer af moderne muslimske og islamistiske organisationer, der spænder over apolitiske, missionerende tendenser til poltiske partier og som alle er repræsenteret i miljøet omkring DIT

${ }^{5}$ Eksempelvis er Shahid Mehdis khutba fra Islamisk Kulturcenter d. 15.11.2009 en ad verbum reproduktion af talen "zâhirat inhirâf al-shabâb" af Abd al-Bârî al-Thabîtî fra al-Masjid al-Nabawî, Medina. Ungdommen er her ikke kilde til fordret reform, men fremhævet pga. dens rolle som ummaens fremtidige fundament. Vægten ligger på ungdommens manglende opdragelse og lydighed (tarbiya, $\operatorname{tâ}^{\prime} a$ ). Den oprindelige khutba findes på:

http://www.mktaba.org/vb/showthread.php?t=5312
} 